Article

\title{
The 2014 Effusive Eruption at Stromboli: New Insights from In Situ and Remote-Sensing Measurements
}

\author{
Federico Di Traglia ${ }^{1, *(1)}$, Sonia Calvari ${ }^{2}{ }^{(1)}$, Luca D'Auria ${ }^{3,4,5}$, Teresa Nolesini ${ }^{6}$, \\ Alessandro Bonaccorso ${ }^{2}$, Alessandro Fornaciai ${ }^{7}$, Antonietta Esposito ${ }^{3}$, Antonio Cristaldi ${ }^{2}$, \\ Massimiliano Favalli ${ }^{7}$ and Nicola Casagli ${ }^{1}$ \\ 1 Dipartimento di Scienze della Terra, Università degli Studi di Firenze, Via La Pira 4, 50121 Firenze, Italy; \\ nicola.casagli@unifi.it \\ 2 Istituto Nazionale di Geofisica e Vulcanologia, Osservatorio Etneo - Sezione di Catania, Piazza Roma 2, \\ 95125 Catania, Italy; sonia.calvari@ingv.it (S.C.); alessandro.bonaccorso@ingv.it (A.B.); \\ antonio.cristaldi@ingv.it (A.C.) \\ 3 Istituto Nazionale di Geofisica e Vulcanologia, Osservatorio Vesuviano - Sezione di Napoli, \\ Via Diocleziano 328, 80124 Napoli, Italy; ldauria@iter.es (L.D.); antonietta.esposito@ingv.it (A.E.) \\ 4 Instituto Volcanológico de Canarias (INVOLCAN), 38320 San Cristóbal de La Laguna, Tenerife, \\ Canary Islands, Spain \\ 5 Instituto Tecnológico y de Energías Renovables (ITER), 38600 Granadilla de Abona, Tenerife, \\ Canary Islands, Spain \\ 6 Centro per la Protezione Civile, Università degli Studi di Firenze, Piazza San Marco 4, 50121 Firenze, Italy; \\ teresa.nolesini@unifi.it \\ 7 Istituto Nazionale di Geofisica e Vulcanologia, Sezione di Pisa, Via della Faggiola 32, 56126 Pisa, Italy; \\ alessandro.fornaciai@ingv.it (A.F.); massimiliano.favalli@ingv.it (M.F.) \\ * Correspondence: federico.ditraglia@unifi.it; Tel.: +39-055-275-5981
}

Received: 15 November 2018; Accepted: 12 December 2018; Published: 14 December 2018

\begin{abstract}
In situ and remote-sensing measurements have been used to characterize the run-up phase and the phenomena that occurred during the August-November 2014 flank eruption at Stromboli. Data comprise videos recorded by the visible and infrared camera network, ground displacement recorded by the permanent-sited Ku-band, Ground-Based Interferometric Synthetic Aperture Radar (GBInSAR) device, seismic signals (band 0.02-10 Hz), and high-resolution Digital Elevation Models (DEMs) reconstructed based on Light Detection and Ranging (LiDAR) data and tri-stereo PLEIADES-1 imagery. This work highlights the importance of considering data from in situ sensors and remote-sensing platforms in monitoring active volcanoes. Comparison of data from live-cams, tremor amplitude, localization of Very-Long-Period (VLP) source and amplitude of explosion quakes, and ground displacements recorded by GBInSAR in the crater terrace provide information about the eruptive activity, nowcasting the shift in eruptive style of explosive to effusive. At the same time, the landslide activity during the run-up and onset phases could be forecasted and tracked using the integration of data from the GBInSAR and the seismic landslide index. Finally, the use of airborne and space-borne DEMs permitted the detection of topographic changes induced by the eruptive activity, allowing for the estimation of a total volume of $3.07 \pm 0.37 \times 10^{6} \mathrm{~m}^{3}$ of the 2014 lava flow field emplaced on the steep Sciara del Fuoco slope.
\end{abstract}

Keywords: Stromboli volcano; landslides; effusive activity; Ground-Based InSAR; infrared live cam; seismic monitoring; PLEIADES; Digital Elevation Models; optical sensors; volcano remote sensing 


\section{Introduction}

Stromboli volcano (Italy; Figure 1), a stratovolcano located at the easternmost end of the Aeolian Archipelago, experienced a flank eruption from August-November 2014 [1-7]. In this paper, in situ and remote-sensing measurements at Stromboli between May and November 2014 are presented. Data comprise videos recorded by the visible and infrared cameras network [8,9] (Figure 1a), ground displacement recorded by the permanent sited $\mathrm{Ku}$-band, Ground-Based Interferometric Synthetic Aperture Radar (GBInSAR) device [10,11], ground displacements in the seismic band (0.02-10 Hz) [12,13] (Figure 1a), and high-resolution Digital Elevation Models (DEMs) reconstructed based on tri-stereo PLEIADES-1 imagery and Light Detection and Ranging (LiDAR) data, respectively. Data allowed us to characterize the precursors and the phenomena that occurred during the eruption, as well as an estimation of the erupted volume.

Stromboli is characterized by persistent Strombolian activity from several vents within a crater terrace area [9,14] (Figure 1b). The volcanic edifice is frequently affected by landslides [15], mainly within the Sciara del Fuoco (SdF; Figure 1b), a collapse depression on the NW flank of the island formed during the last $13 \mathrm{ka}[16,17]$. Landslides triggered tsunamis on average every 20 years [18], especially during flank eruptions or paroxysmal explosions $[12,19,20]$. Small to large volcano slope instability characterized the initial phases of the last four flank eruptions (1985-86, 2002-03, 2007, 2014) [21-24], triggering tsunamis only during the 2002-03 event [22,25].

The last flank eruption started at Stromboli on 7 August 2014, preceded by 2 months of increased Strombolian activity and several lava overflows from the craters expanding along the SdF [2,26]. Overflows were often accompanied by landslides along the SdF [7], described as rock-falls and/or gravel slides, evolving down slope to gravel flows (Figure 2a). The onset of the 2014 flank eruption (6-7 August) involved the breaching of the summit cone with emplacement of a landslide along the SdF (Figure 2b), the opening of an eruptive fissure on the NE flank of the cone [24], and the effusion of lava from the crater rim at first and from the eruptive fissure later, feeding the 2014 lava flow field $[4,5,7]$. The eruption was characterized by the lava effusion in the SdF from a fissure at $650 \mathrm{~m}$ above sea level (a.s.l.) that lasted until 13 November 2014 [4].

The 2014 lava flow field was similar to others erupted from high-elevation vents (as described for the 2002-2003 lava flow field by [27]), comprising: (i) a series of tumuli and lava flows around the effusive vent at $\sim 650 \mathrm{~m}$ a.s.l. (proximal shield); (ii) a medial zone fed by small flows, and characterized by frequent lava crumbling down slope and producing a debris field; (iii) a basal toe composed of the debris flow field emplaced above the stacked lava delta [28]. The erupted volume has been estimated to be $7.4 \times 10^{6} \mathrm{~m}^{3}$ by [4] and $\sim 5.5 \times 10^{6} \mathrm{~m}^{3}$ by [5].

\section{Materials and Methods}

\subsection{The Camera Monitoring Network (Istituto Nazionale di Geofisica e Vulcanologia, Osservatorio Etneo - INGV-OE)}

The camera monitoring network comprises thermal infrared and visible cameras located at Il Pizzo, at $\sim 918 \mathrm{~m}$ elevation and $\sim 250 \mathrm{~m}$ from the craters, plus visible and thermal infrared cameras (SQV400 and SQT400, respectively) at $400 \mathrm{~m}$ elevation on the $\mathrm{N}$ flank of the SdF and $\sim 800 \mathrm{~m}$ from the craters (Figure 1a). The SQV400 and SQT400 cameras allow a view from NE of the North-East Crater NEC area (Figure 1a) and of the upper eastern sector of the SdF. An additional thermal camera installed in July 2014, is located at the lower eastern end of the SdF ( 190 m a.s.l., Figure 1b) and is focused on the lower portion of the slope between $\sim 400 \mathrm{~m}$ and the $\mathrm{N}$ coast line. To obtain a description of the eruptive activity, the total number of explosive events that occurred during each day of cloud-free observation was manually counted and plotted as an integer versus time. On average, between 24 July 2014 and 10 August $2014, \sim 30 \%$ of the days were affected by clouds and/or by system failure. In such cases data are lacking. 


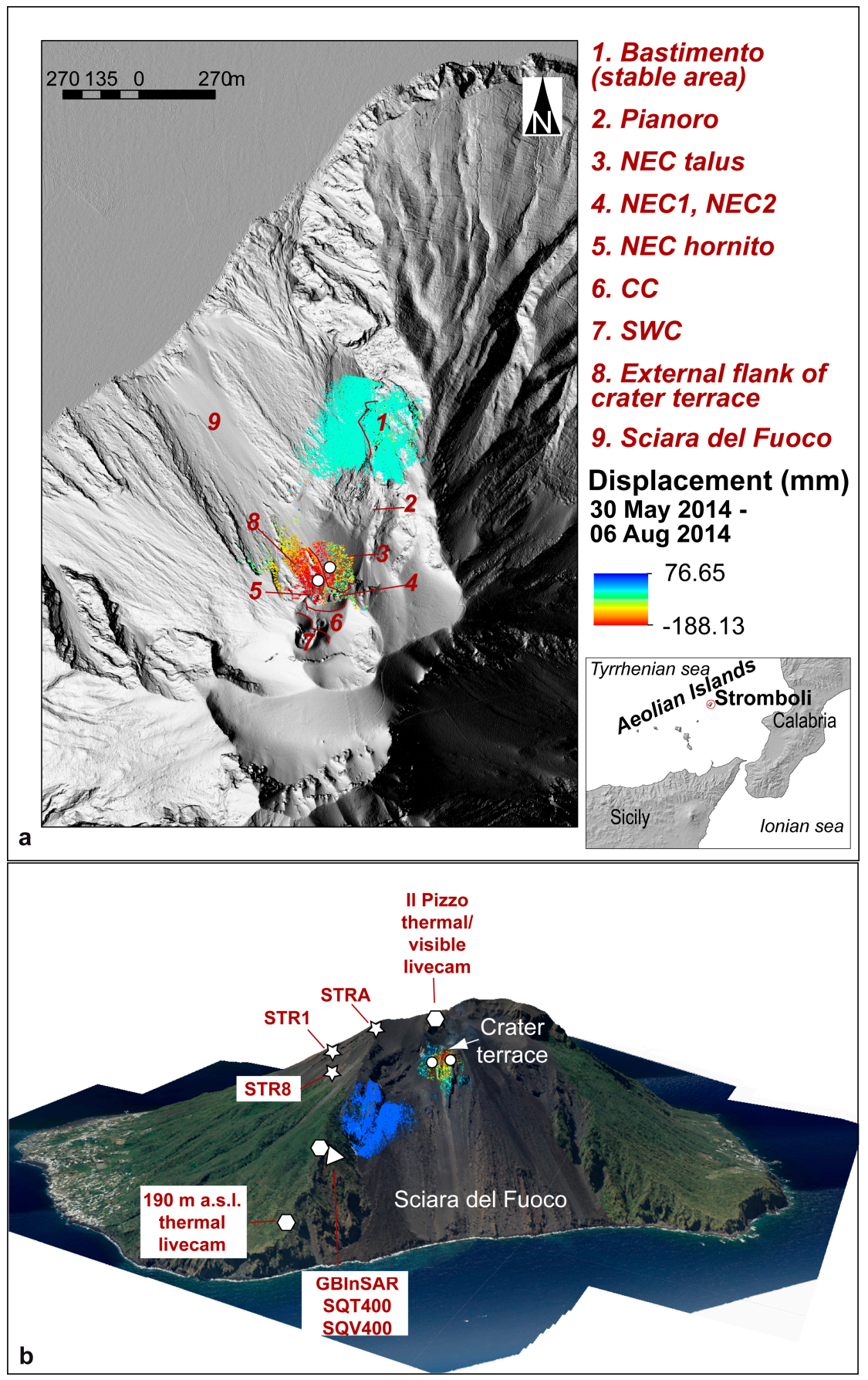

Figure 1. (a) Geographic setting of the Island of Stromboli, located at the easternmost end of the Aeolian Archipelago, and names of the summit vents within the crater terrace. NEC: North-East Crater area; CC: Central Crater area; SWC: South-West Crater area (b) 3D-view of the investigated sectors observed from north, highlighting the location of the measurement stations used in this work. STR1, STR8, and STRA: broadband seismic stations. SQT400 and SQV400: thermal and visible live cam, respectively. In both (a) and (b), the line of sight (LOS) displacement map produced by the GBInSAR apparatus between 30 May 2014 and 6 August 2014 is also shown, highlighting the strong inflation of the crater terrace and the stability of the Sciara del Fuoco before the 2014 flank eruption. The measure-areas of the time-series are indicated by white circles. All Digital data were collected in the Projected coordinate system: WGS 1984 UTM zone 33 Projection: Transverse Mercatore. Maps were generated using ESRI ArcGIS CAMPUS (Università degli Studi di Firenze Licence; http:/ / www.siaf.unifi.it/vp-1275-arcgis-licenza-campus.html). 

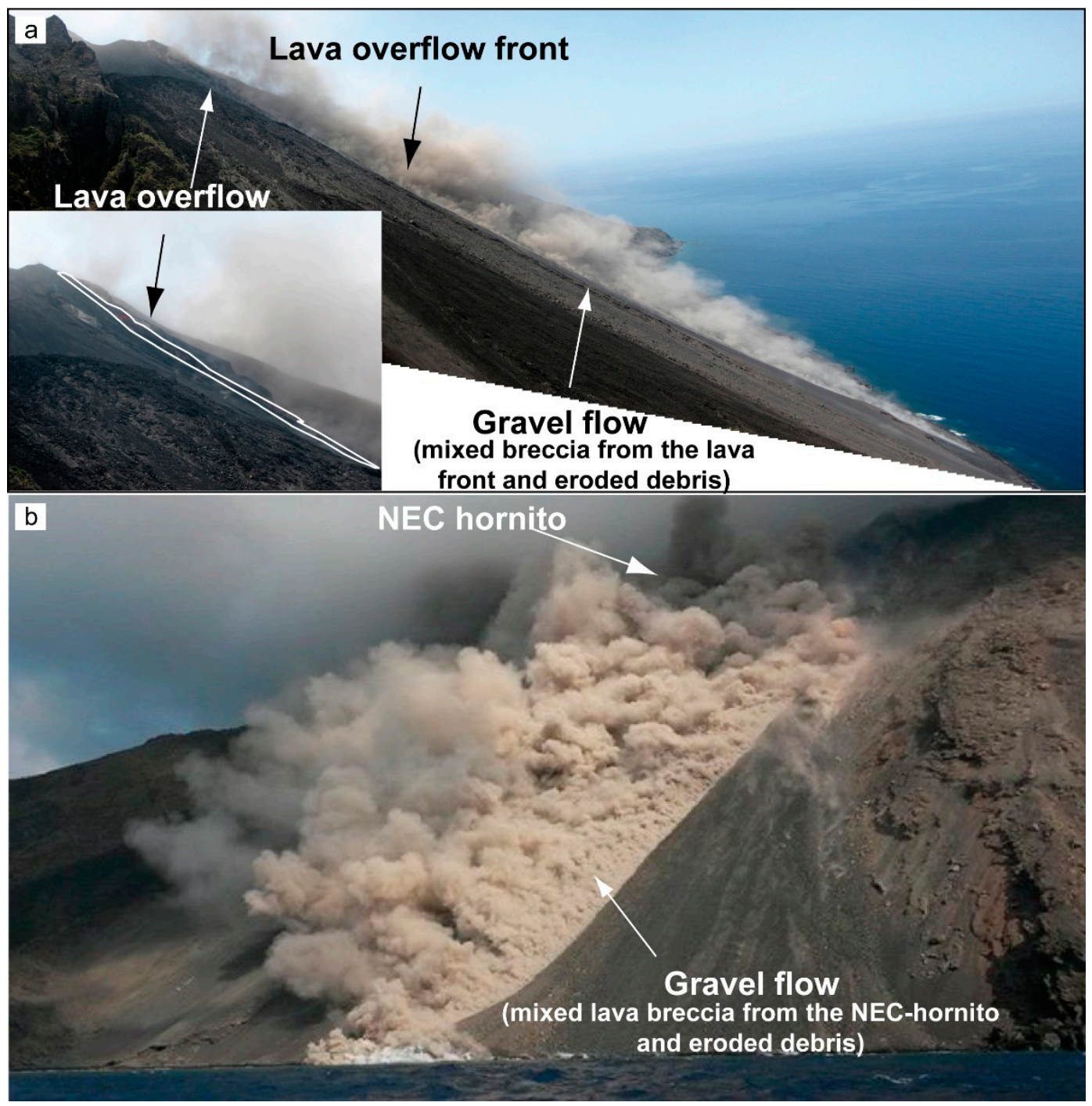

Figure 2. (a) Gravel flow associated with the 7 July 2014 overflow. The landslide is composed by mixed breccia from the overflow front and the (mainly fine-grained) debris eroded along the Sciara del Fuoco (photo taken by the Università degli Studi di Firenze personnel during field survey). (b) Landslides associated with the collapse of the NEC-hornito, occurred on 6 August 2014 (photo taken by UNIFI personnel during boat survey).

\subsection{Seismic Network (Istituto Nazionale di Geofisica e Vulcanologia, Osservatorio Vesuviano - INGV-OV)}

During the 2014 eruption the seismic broadband network of Stromboli [29] was operating with 10 broadband seismic stations. In this work, we used data from 3 seismic stations (Figure 1b). STR1 is located on the flank of the volcano at an elevation of about $560 \mathrm{~m}$ and has the longest and most complete record of seismological parameters. STRA is located at about $840 \mathrm{~m}$, it is the closest to the summit craters, therefore is particularly suitable to study the dynamics of explosive activity. Lastly, STR8, located at about $570 \mathrm{~m}$, is the closest to the SdF, hence it is the best suited to study seismic signals related to landslides in this area.

The seismological parameters considered here are: the amplitude of volcanic tremor, the amplitude of explosion quakes and the inclination of the seismic polarization in the Very-Long-Period (VLP) band $(0.05-0.5 \mathrm{~Hz})$. We also performed the analysis of seismic signals, using neural networks, which allows detecting signals related to landslides occurring along the SdF [30]. Landslides signals have shown to be a reliable precursor of effusive activity at Stromboli. Their occurrence rate increased markedly during the onset of the previous effusive eruption in 2007 [12]. To quantify the intensity of landslide 
activity, Esposito, et al. [31] defined a landslide index following a fuzzy logic scheme. This parameter varies smoothly between 0 and 1 , with 0 indicating a low probability of ongoing landslide activity and, conversely, 1 indicating a high probability of occurrence.

\subsection{GBInSAR}

InSAR technique has been successfully used to catch slope deformation at active volcanoes [31-33], though Synthetic Aperture Radar (SAR) satellites are no longer able to follow the evolution of very fast slope deformation. Conversely, given their repeat time (minutes), GBInSAR can correctly measure very fast displacements, thus the InSAR technique is ideal for monitoring, surveillance, and early-warning applications [24,34]. At Stromboli, a GBInSAR apparatus is working since 2003, located in a stable area $\mathrm{N}$ of the SdF (Figure $1 \mathrm{~b}$ ), and consisting of a transmitting and a receiving antenna moving along a $3 \mathrm{~m}$ long rail [10]. The GBInSAR, working in Ku-band, has also the great advantage of penetrating the dust clouds (abundant especially during the collapse events, see Figure 2), and working in every light and atmospheric condition. The GBInSAR measures ground displacement along the line of sight (LOS; Figure 1a,b), by computing via cross correlation the phase differences between the backscattered signals associated with two SAR images. Range and cross-range resolution are on average $2 \times 2 \mathrm{~m}$, with a measured displacement precision lower than $1 \mathrm{~mm}[10,11]$. Due to the short-elapsed time (11 $\mathrm{min}$ ) between two subsequent measurements, the interferometric displacements are usually smaller than half the wavelength $(8.6 \mathrm{~mm}$ for the Ku-band), therefore unwrapping procedures are generally not necessary [10]. Moreover, unwrapping is a time-consuming process, avoiding the operational use of the GBInSAR during crisis management. For the Stromboli GBInSAR images, a coherence mask (threshold equal to 0.8) is set to reduce the noisy areas of the interferogram [11]. Displacement maps and time-series are obtained "stacking" the interferogram phase with a displacement measurement precision of $0.5 \mathrm{~mm}$, obtained using 1-h averaged SAR images [35].

\subsection{Topographic Data and Co-Registration}

Topographic change detection of Stromboli island due to the 2014 eruption was performed by comparing pre- and post- eruptive DEMs, the former generated from airborne LiDAR data and the post-eruption DEM from PLEIADES-1 satellite data.

The pre-2014 LiDAR-DEM was obtained elaborating the 3D point cloud acquired during an airborne survey carried on May 2012 by "BLOM Compagnia Generale Ripreseaeree S.P.A." (www.blomasa.com). The data were acquired using the Leica ADS80 sensor which has instrumental vertical and horizontal accuracy of $\pm 10 / 20 \mathrm{~cm}$ and $\pm 25 \mathrm{~cm}$, respectively (see [36] for 2012 DEM features). The acquired point cloud has a mean point density of $8 \mathrm{pt} / \mathrm{m}^{2}$.

The post-2014 DEM was derived from the very high-resolution (VHR) tri-stereo optical imagery from the PLEIADES-1 satellites. PLEIADES-1 constellation is composed by two satellites, PLEIADES-1A (PHR1A) and PLEIADES-1B (PHR1B). These satellites can sense three or more synchronous images of the same area, with angles variable between $\sim 6^{\circ} \mathrm{e} \sim 28^{\circ}$. The stereoscopic triplet is composed of three nearly simultaneously acquired images, one backward looking, one forward looking, plus a third near-nadir image [37-41]. Tri-stereo images are $100 \%$ cloud free and were acquired by PHR1A on 27 May 2017, with a total areal coverage of $58 \mathrm{~km}^{2}$. This acquisition mode permits to obtain a DEM using the photogrammetric processing of three images (tri-stereo mode), with a pixel xy resolution of $1 \mathrm{~m} \times 1 \mathrm{~m}$. The dataset comprised also VHR optical imagery $(0.5 \mathrm{~m} \times 0.5 \mathrm{~m}$ resolution for Panchromatic $+2 \mathrm{~m} \times 2 \mathrm{~m}$ Multispectral data). To assess the accuracy of the heights and their horizontal position in the Pleiades-1 DEM, six Ground-Control Points (GCPs) were collected on the map database (Cartographic XY standard deviation: $0.15 \mathrm{~m}$ ). Nine tie points were automatically collected in the images. A block adjustment including all the satellite scenes was performed. The block adjustment was validated when the following accuracy was achieved: (i) pixel xy bias smaller than 0.3 pixels; (ii) pixel xy standard deviation smaller than 0.3 pixels; (iii) pixel xy maximum smaller than 2 pixels. 
Topographic change detection using multi-temporal DEMs was performed by differencing two DEMs of the same area derived from data taken at different time. This calculation is often affected by errors depending on mismatches between the two DEMs, which lead to artefact $\Delta z$ [42]. This error can be detected and reduced by measuring and minimizing the DEM differences in areas where the two DEMs are supposed to be equal, i.e., those areas not reasonably affected by relevant natural changes.

The 2012 and 2017 topographic data were here co-registered by minimizing the root mean square (RMS) error between two DEMs. The methods used iteratively vary the three angles of rotation, the translation, and the magnification or reduction factor of one DEM using a custom-made algorithm based on the MINUIT minimization library [43], as described by [44-46]. MINUIT is a tool to find the minimum value of multi-parameter functions and can be freely downloaded (http://www.cern.ch/minuit). The LiDAR-PLEIADES DEMs co-registration was performed by calculating the minimization parameters for the whole volcano with the exclusion of the investigated areas (i.e., the SdF). The RMS error in this case is given by the MINUIT output. The 2012 LiDAR was used as reference for co-registering the PLEIADES DEM. It is worth emphasizing that this RMS error is the root mean square residuals (in elevation) between a 3D point cloud and the reference DEM, rather than a true absolute error. Co-registration decreased the RMS error from the initial $3.37 \mathrm{~m}$ to the final $1.27 \mathrm{~m}$.

The differences between the co-registered DEMs were used to detect and outline the extent of the areas affected by topographic changes in the considered time spam, and to calculate the volume and thickness variations inside them. Moreover, the perimeters of observed changes were double-checked using the ortho-rectified PLEIADES-1 images. Field surveys also strengthened data interpretation.

Volume (V) emplaced or lost between two acquisitions was calculated from the DEM difference according to the equation:

$$
V=\sum_{i} \Delta x^{2} \Delta z_{i}
$$

(see [42] and references therein), where $x$ is the grid step and $z_{i}$ is the height variation within the grid cell $i$. These values were then summed up for all the cells in the selected areas in which we want to calculate volume changes.

The residual volume errors were calculated as:

$$
\operatorname{Err}_{(\mathrm{V}, \text { high })}=\mathrm{A} \sigma_{\Delta \mathrm{z}}
$$

where A is the investigated area and $\sigma_{\Delta z}$ is the co-registration residual RMS error between the two DEMs. Following [42], this formula assumes that the errors were completely correlated, and thus the volume error calculated as above is overestimated.

\section{Results}

Explosive activity at Stromboli from the crater terrace was at an average of $\sim 10$ explosions $\mathrm{h}^{-1}$ during the first four months of 2014 (INGV Reports, available at www.ct.ingv.it). Between end of June-early July, the explosion number peaked at $\sim 25$ explosions $\mathrm{h}^{-1}$ (INGV Reports, available at www.ct.ingv.it), when also several lava flows poured out from the South-West crater (SWC, Figure 1a), and from two of the three vents located in the NEC area (NEC1 and NEC-hornito, Figure 1a, Table 1, Supplementary Materials), spreading along the SdF. Between 22 June and 5 August 2014, several powerful explosions and small landslides along the SdF occurred (Supplementary Materials).

The GBInSAR recorded an increase in the LOS displacement rate directed towards the sensor in the crater terrace area, indicating inflation of the summit plumbing system, starting from 30 May 2014 (Figure 3B,C). The following months (June-early August 2014) were characterized by slightly fluctuating displacement rate, with values always above the threshold that distinguishes the anomalous from the persistent activity ( $>0.05 \mathrm{~mm} / \mathrm{h}$ directed towards the sensor; as defined by [11]). A small deflation of the crater terrace occurred around 24 July 2014, after the output of several small overflows, 
then a more rapid inflation of the crater terrace, and a week later also of the NEC-talus, was observed (Figure 3C).

Table 1. Summary of the eruptive activity during the run-up and onset phases of the 2014 flank eruption, as derived from the camera monitoring network.

\begin{tabular}{|c|c|}
\hline Date & Live-Cams Observations \\
\hline 30 May 2014-31 Jul 2014 & $\begin{array}{c}\text { Frequent explosive activity ( } 15 \text { explosions/hour) } \\
\text { Overflows } \\
\text { Landslides }\end{array}$ \\
\hline 01 Aug 2014-05 Aug 2014 & Increased explosion frequency (up to 30 explosions/hour) \\
\hline 06 Aug 2014 at 08:50 & Overflow (between NEC2 and NEC-hornito) \\
\hline 06 Aug 2014 at 11:00 & Arcuate fractures on the NE crater rim between NEC1 and NEC-hornito \\
\hline 06 Aug 2014 at 12:22 & First incandescent blocks from the NEC2/NEC-hornito into the sea \\
\hline 06 Aug 2014 at 12:29 & Overflow (between NEC-hornito and SWC) \\
\hline 06 Aug 2014 12:32-13:00 & Landslide ( $\mathrm{N}$ flank of the crater terrace) \\
\hline 06 Aug 2014 12:35-13:00 & Incandescent blocks accumulation along the coast \\
\hline 06 Aug 2014 at 13:08 & Overflow from NEC-hornito reached the coast \\
\hline 06 Aug 2014 14:05-14:08 & $\begin{array}{l}\text { Three hot "gravel flows" from the NEC-hornito along the SdF, reached the coast and } \\
\text { went on spreading along the sea surface for several tens of meters }\end{array}$ \\
\hline 06 Aug 2014 at 14:50 & Overflow from NEC-hornito reached the coast \\
\hline 06 Aug 2014 at 15:46 & Overflow from NEC-hornito reached the coast \\
\hline 06 Aug 2014 at 16:02 & Hot "gravel flows" from the NEC-hornito along the SdF \\
\hline 06 Aug 2014 at 16:08 & Overflow from NEC-hornito reached the coast \\
\hline 07 Aug $2014 \sim 02: 30$ & Hot "gravel flows" from the NEC-hornito along the SdF \\
\hline 07 Aug $2014 \sim 03: 00$ & $\begin{array}{l}\text { - NEC-hornito lava decreased } \\
\text { - Explosive activity from NEC increased } \\
\text { - Increased size of the hot avalanche deposit }\end{array}$ \\
\hline 07 Aug 2014 at 03:40 & Hot "gravel flows" from the NEC onto the Pianoro flat area \\
\hline 07 Aug 2014 04:01 & $\begin{array}{l}\text { NE flank of NEC1 started to collapse } \\
\text { Lava flow from the NEC towards the Pianoro flat area } \\
\text { Hot "gravel flows" from the NEC-talus onto the Pianoro flat area and along the SdF }\end{array}$ \\
\hline 07 Aug 2014 05:01 & Downslope curved fracture opened on the flank of the cone \\
\hline 07 Aug 2014 05:04-05:16 & $\begin{array}{l}\text { V1 opened at } 05: 04 \text { and V2 at } 05: 16 \text {, both at } \sim 650 \mathrm{~m} \text { a.s.l. } \\
\text { Landslides onto the Pianoro flat area and along the SdF } \\
\text { Lava flow onto the Pianoro flat area }\end{array}$ \\
\hline 07 Aug 2014 05:30 & Lava flow along the SdF \\
\hline 07 Aug $2014 \sim 06: 02$ & Hot "gravel flows" from the NEC-talus reached the coast \\
\hline 07 Aug 2014 06:24 & Lava flow from V1 reached the coast \\
\hline
\end{tabular}

One of the most striking features in the seismological parameters during the 2014 eruption was the progressive, but rapid increase in both volcanic tremor and explosion-quake amplitude, starting approximately on 2 August 2014 (Figure 3D,E). Both quantities showed a steady increment, followed by a sudden drop in the amplitudes occurring about on 6 August 2014 at 12:00 (Figure 3D,E). This event was associated with the onset of the effusive activity on 6 August 2014, clearly evidenced by the landslide index, approaching the value of 1 in the same period (Figure 3A). However, a detailed analysis of the VLP polarization (Figure 3F), which is a good indicator of changes in the level of the magmatic column within the conduits, revealed that the most significant drop in the magma column level occurred only at about 04:00 of 7 August 2014, just before the effusive vent opened at $650 \mathrm{~m}$ a.s.l. (V1 and V2; see Table 1, Figure 4, and Supplementary Materials for further details).

The displacement rate suddenly increased on 5 August 2014 for both the external flank of the crater terrace and the NEC-talus, reaching their maximum on 6 August 2014 (Figure 3B,C). An increase 
in the explosion rate and intensity was recorded on 6 August 2014 morning, especially from the NEC. Several overflows occurred since 08:50 (flows F1 to F3 in Figure 4), and the rim of the crater terrace started to be clearly unstable since 11:00, when three arcuate fractures on the NE crater rim formed between NEC1 and NEC-hornito (Table 1, Supplementary Materials).

The GBInSAR recorded an increase in the displacement rate (since 10:00 of 6 August 2014) in both the external flank of the crater terrace and the NEC-talus. The maximum displacement was recorded mainly in the NEC-hornito area (Figure 5a). Rock-falls started to occur at 12:22, and soon after a lava flow erupted from the saddle between the NEC-hornito and the SWC (Flow F2A in Figure 4a), expanding $\mathrm{N}$ along the SdF (12:32). Between 13:00 and 14:21, the GBInSAR recorded a large loss in the SAR coherence in the NEC-hornito, consistent with the occurrence of fast-moving material (landslides and/or overflows) from the NEC-hornito (Figure 5b). Three landslides (starting at 14:05, 14:06, and 14:07, Figure 6), described as rock-falls/gravel slides evolving in rapid gravel flows, were directly observed (Figure $2 \mathrm{~b}$ ). The collapse scar observed on a photo taken from helicopter (Figure 2a) had an estimated size of $\sim 40 \mathrm{~m}$ width, $30 \mathrm{~m}$ high and $20 \mathrm{~m}$ depth, with a total collapsed volume estimated in $\sim 24,000 \mathrm{~m}^{3}$. Effusive vents moved northward from the NEC-hornito towards the NEC1. Afterwards, the displacement towards the sensor (up to $236 \mathrm{~mm} \mathrm{~h}^{-1}$ ) shifted from the NEC-hornito towards the NEC-talus (Figure 5c). Between 01:29 and 01:32 of 7 August 2014 (Figure 5c), the GBInSAR detected the formation of a fracture upslope of the NEC-talus. At the same time, the GBInSAR recorded an inversion in the LOS displacement rate (movements directed away from the sensor) in the crater terrace area, coherent with the deflation of the shallow conduit (Figure 5d).
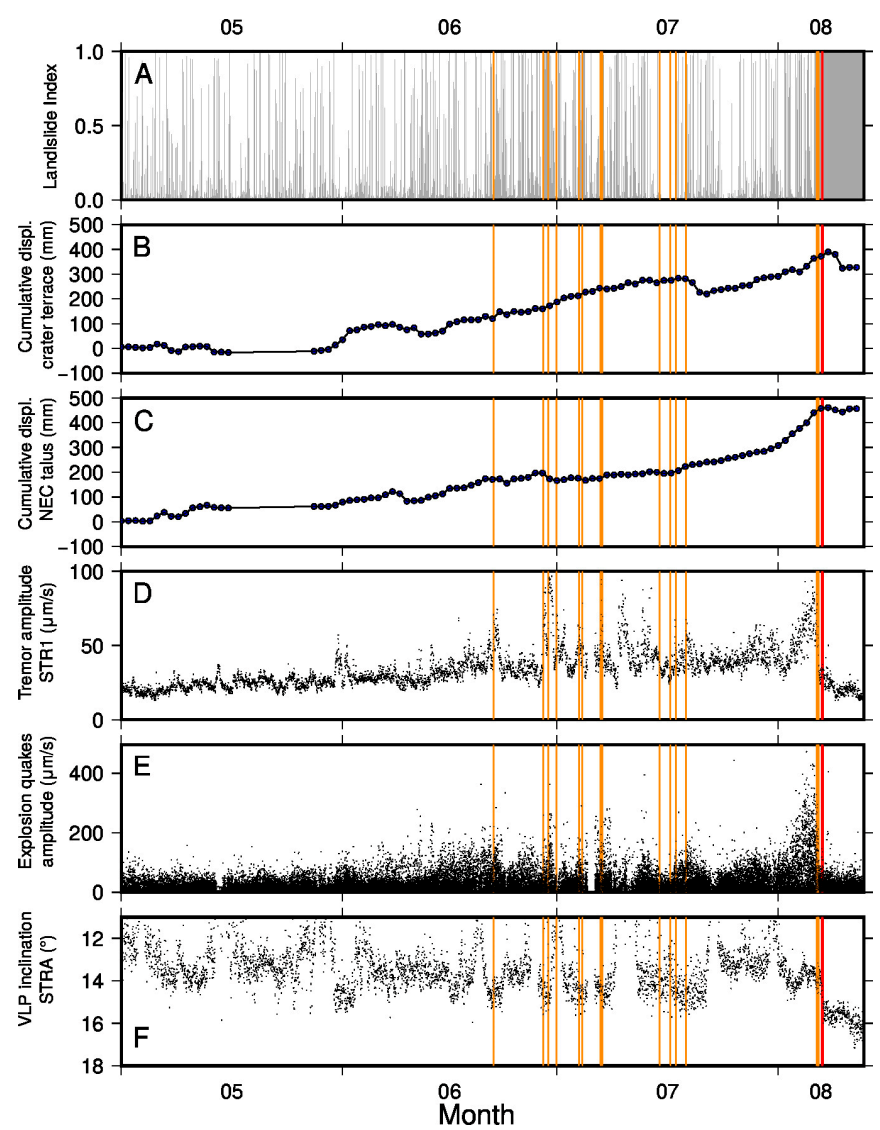

Figure 3. Relevant geophysical time-series from May to August 2014. (A) Landslide index derived from seismic data; GBInSAR cumulative displacement data for $(B)$ the crater terrace and $(C)$ for the NEC-talus. (D) Volcanic tremor amplitude at station STR1. (E) Explosion-quake amplitudes at station STR1. (F) VLP polarization inclination at station STRA. 


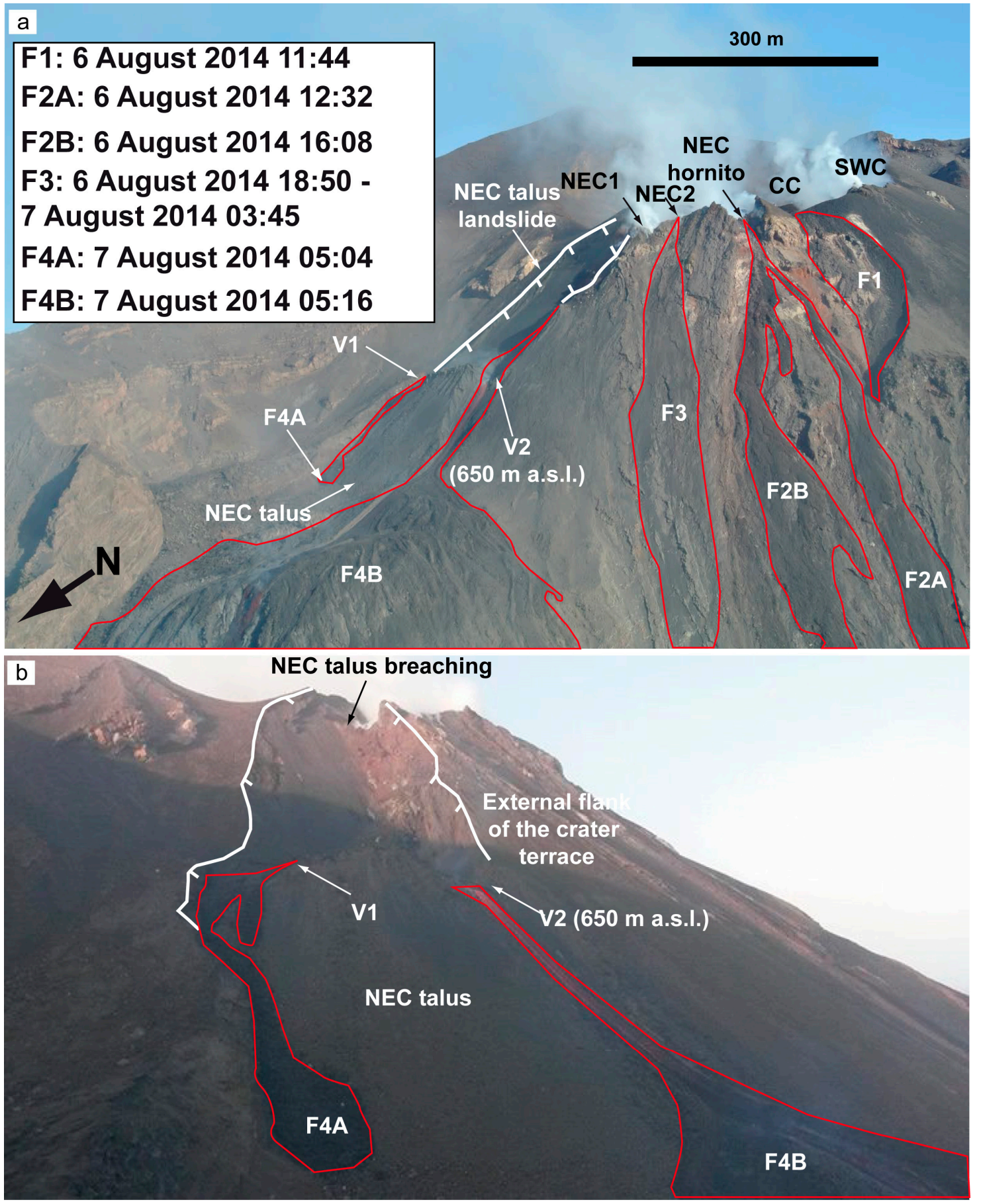

Figure 4. (a) The external flank of the crater terrace after the onset of the 2014 flank eruption (photo taken by INGV personnel on 11 August 2014 from helicopter survey). Lava overflows emitted during the run-up phase (F1 to F3) and lava flow produced during and after the onset (F4A and F4B) are also reported. (b) Detail of the NEC-talus area highlighting the scar produced during the onset of the eruption (7 August 2014), the first lava flow after crater breaching (F4A, erupted from vent V1), the upper portion of the 2014 lava flow field (F4B), and the vent of the 2014 flank eruption (V2) (photo taken by UNIFI personnel on 8 October 2014 from field survey). It is interesting to note the internal stratification in the NEC-talus remnants (consisting of volcaniclastic levels) that are continuous in all the inner walls of the landslide scar. 

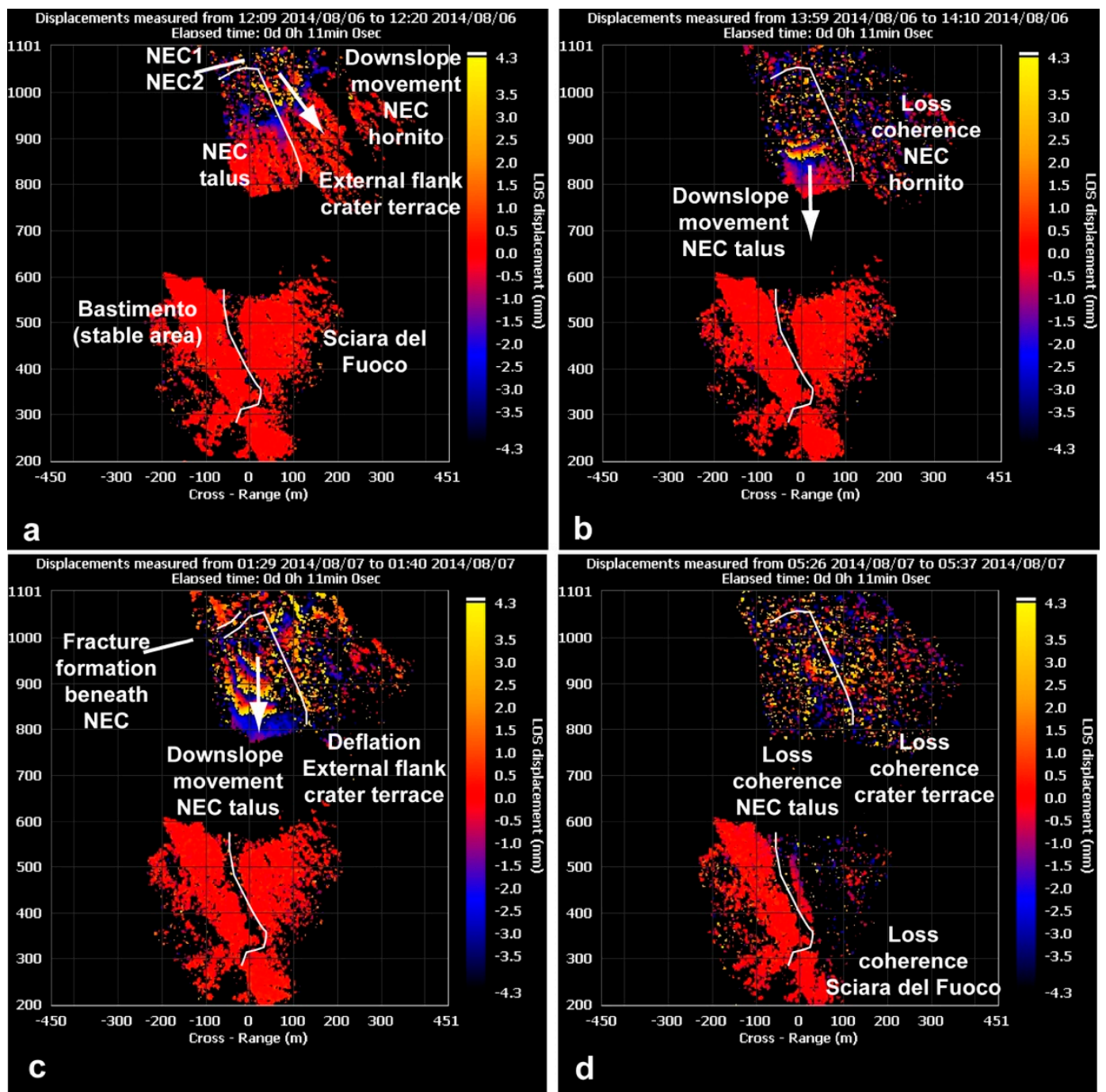

Figure 5. GBInSAR interferograms formed using a pair of images recorded between (a) the 12:09 and 12:20 on 6 August 2014, evidencing the instability of the NEC-hornito; (b) the 13:59 and 14:10 on 6 August 2014, evidencing the instability of the NEC-talus; (c) the 01:29 and 01:40 on 7 August 2014, evidencing the concomitant instability of the NEC-talus and the deflation of the crater terrace, coherent with the sliding of the NEC-talus induced by the NE-ward magma migration from the crater terrace; (d) the 05:26 and 05:37 on 7 August 2014, characterized by loss in SAR coherence due to fast movement both in the crater area (sliding processes) and along the SdF (lava flow emplacement). Interferograms in $(\mathbf{a}-\mathbf{c})$ are affected by phase wrapping.

At 05:04 V1 opened at $\sim 650 \mathrm{~m}$ a.s.l. (Figure 4) and at 05:08 the NE flank of NEC1 started collapsing, as evidenced by the associated high-frequency seismic signal (Figure 7). At 05:01, the live cam detected a downslope curved fracture opened on the flank of the NEC cone, followed at 05:16 by the opening of the effusive vent V2 at $\sim 650 \mathrm{~m}$ a.s.l. (Table 1 and Figure 4 ). The onset of the increased landslide activity occurred at 05:08, and its amplitude reached a peak at $\sim 05: 24$, i.e., during the opening of V1 and V2 (Table 1 and Figure 7). With the shift of the active vent from V1 to V2, a lava flow started spreading along the Pianoro (Supplementary Materials) and the flank eruption started.

We analyzed in detail $24 \mathrm{~h}$ of high-frequency seismic signals related to landslide activity along the SdF starting from 10:00 on 6 August 2014 (Figure 7B). Between 10:00 and 18:00 on 6 August 2014, the repeated lava overflows triggered a moderate landslide activity along SdF (Figure 7A). Before the opening of vent V1, at 04:01 on 6 August, we observed a progressive increase in the landslides, which dropped just after this event. However, the clear onset of the increased landslide activity 
occurred at 05:08 and the amplitude reached a peak at around 05:24, a few minutes after the opening of vent V2 at 05:16. After a pause of about $8 \mathrm{~min}$, the landslide activity resumed at 05:32 and lasted for about $1 \mathrm{~h}$, before reaching a stationary level (slightly higher than the value observed before 05:08) and possibly related to the ongoing lava flow (Figure 7C).

The GBInSAR recorded a large loss in coherence at the NEC-talus and the SdF area, consistent with the onset of the effusion (Figure 5D). At 05:29 the flow had travelled the Pianoro flat surface and at 05:30 started to expand along the SdF steep slope (Supplementary Materials). Here it formed at least 5 lava flow branches (Supplementary Materials), reaching the coast with a hot avalanche 30 min later (Table 1, Supplementary Materials). The landslide activity resumed at 05:32, and the collapse lasted for about $1 \mathrm{~h}$, coherent with several landslides' pulses (Figure 8). By 06:24 several lava branches reached the sea, forming a lava fan $~ 500 \mathrm{~m}$ wide (Table 1, Supplementary Materials). Effusive and explosive activity declined between 7 and 8 August 2014, with only one lava flow active along the coast and deeper magma level within the feeder conduit, evidenced by more collimated jets produced during the explosive activity at the summit vents (Table 1, Supplementary Materials).
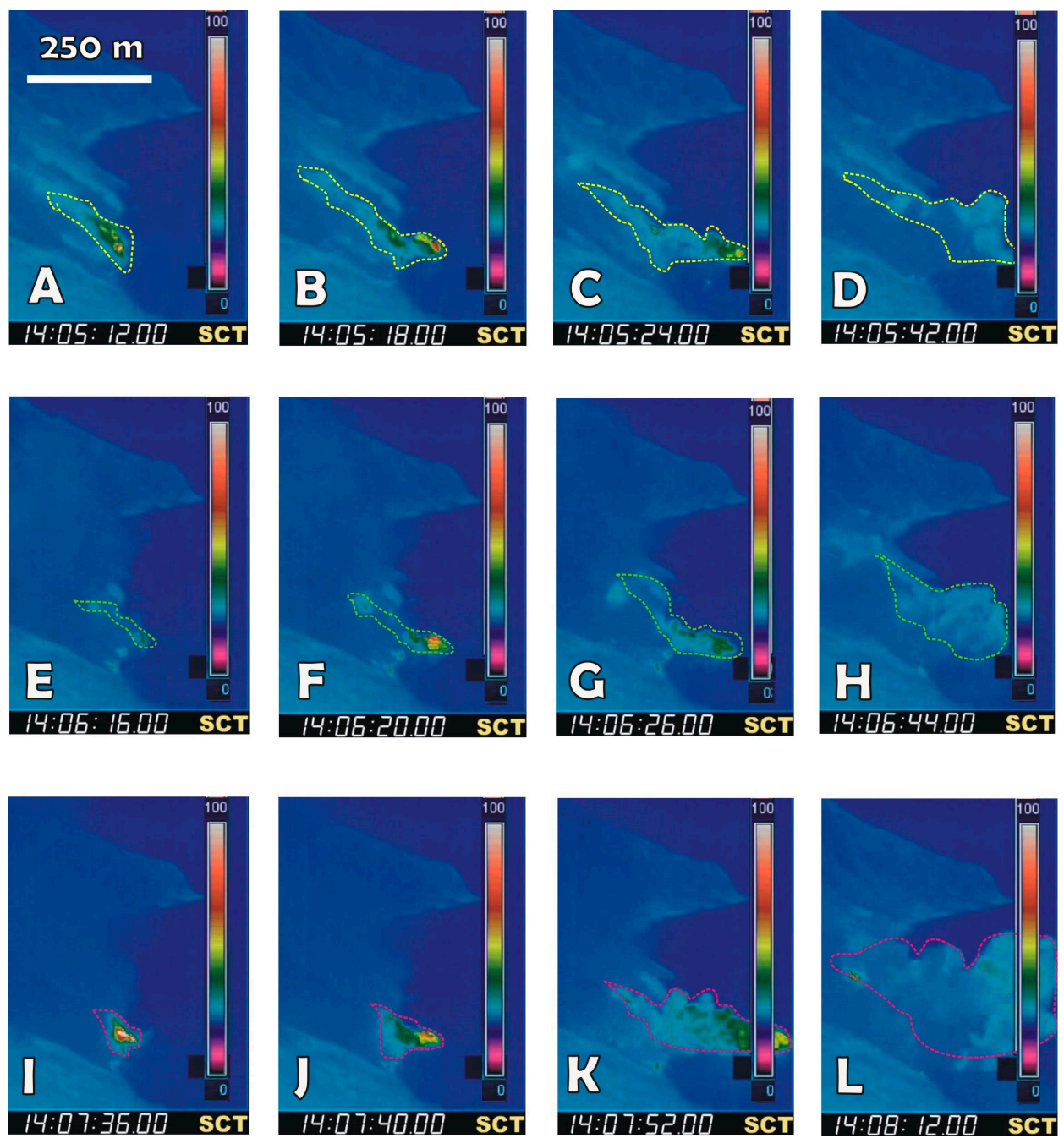

Figure 6. Thermal images recorded by the SCT camera located at Labronzo, $100 \mathrm{~m}$ a.s.l. (see Figure $1 \mathrm{~b}$ for location), showing the hot "gravel flows" that reached the sea on 6 August 2014, at 14:05 (A-D), 14:06 (E-H) and 14:07 (I-L), spreading on the sea surface. Temperature is in ${ }^{\circ} \mathrm{C}$. The velocities of the three landslides of hot blocks in the frontal region were $9.8 \mathrm{~m} \mathrm{~s}^{-1}, 5.9 \mathrm{~m} \mathrm{~s}^{-1}$ and $9.8 \mathrm{~m} \mathrm{~s}^{-1}$, respectively, based on web-cameras measurements. 
Loss in SAR coherence persisted until 8 August 2014 on the whole scene illuminated by the GBInSAR device. In the crater terrace, the coherence increased again since 9 August 2014 when no explosive activity was observed from the monitoring cameras, and the GBInSAR recorded displacement away from the sensor until late September indicating deflation of the summit.

The images recorded by the thermal camera located at Il Pizzo (SPT; see Figure 1B for location) showed significant morphology changes of the summit craters since 9 August 2014, showing that the apex of cones and hornitos within NEC1, NEC-hornito and SWC had been removed by the several collapses and hot "gravel flows" of the previous days. The thermal images displayed also a much lower temperature of the whole crater area, indicating a decline in the explosive activity. Likewise, the rate of effusion decreased significantly from the previous day, with only one wider lava flow starting from the eruptive fissure and replacing the $4-5$ branches of the previous day. This flow was reaching the coast forming a narrow channel apparently cooling down, with overflows sometimes spilling over the channel levees.

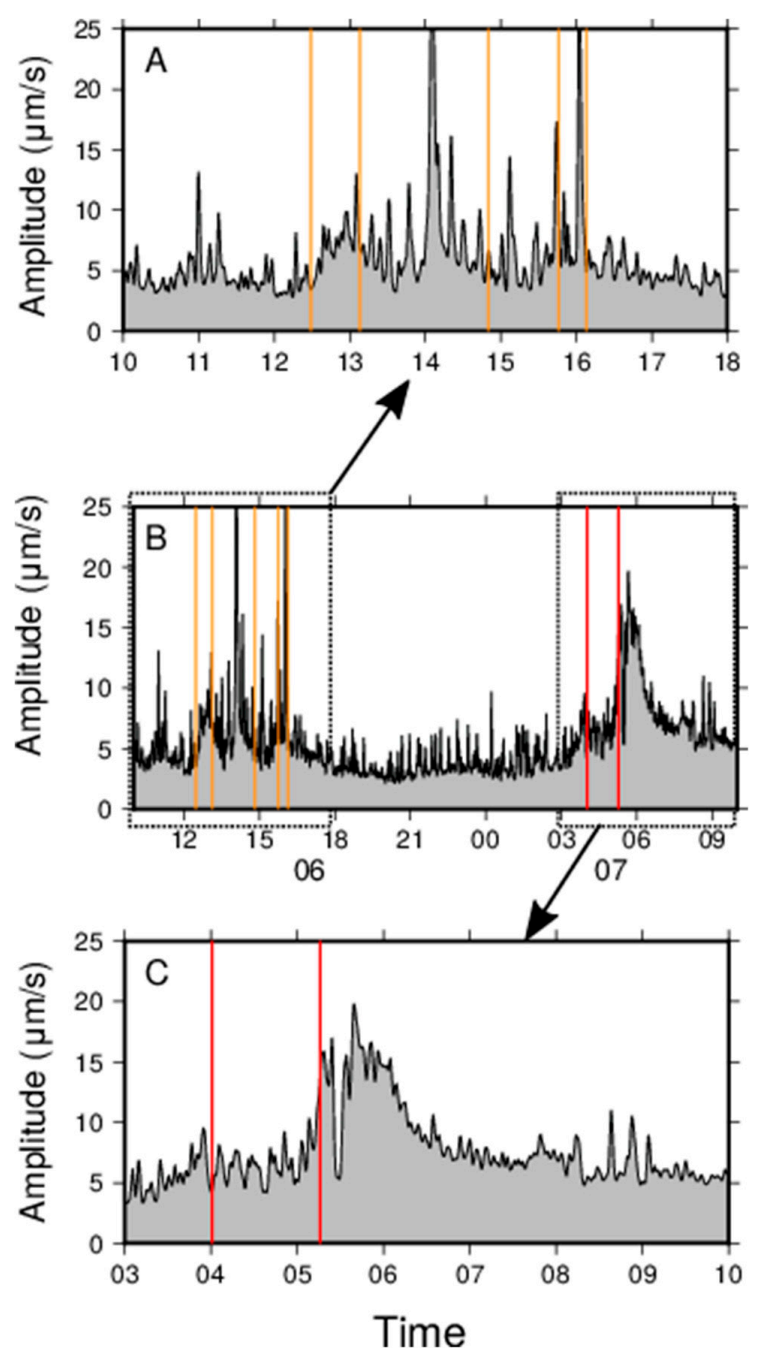

Figure 7. Plot of the high-frequency $(>10 \mathrm{~Hz})$ seismic amplitudes averaged over $10 \mathrm{~s}$ windows (station STR8, EW seismic component) for: (A) details referred to the time interval 10:00-18:00 of 6 August 2014, highlighting the signals associated with landslides that occurred soon after the onset of the overflows, whose onset is marked by orange vertical lines; (B) the time interval 10:00 on 6 August 2014-10:00 on 7 August 2014; (C) details referred to the time interval 03:00-10:00 of 7 August 2014, highlighting the signals associated with landslides that occurred at the opening V1 and V2 vents (red vertical lines). 
Until 15 October 2014 the GBInSAR recorded displacement towards the sensor, indicating inflation of the crater area. Afterwards, very low displacement rate $(<0.05 \mathrm{~mm} / \mathrm{h})$ oscillating between away and towards the sensor, have been recorded. In the SdF area, after the onset of the 2014 flank eruption, the radar recorded a very low coherence for three days; this was related to the initial fast-moving lava flow. Since 10 August 2014, low coherence zones were related only to a small part of the monitored scenario, corresponding to active lava tongues, while the rest of the monitored SdF showed variable displacement rates $(1-10 \mathrm{~mm} / \mathrm{h})$.

The seismic signals related to minor landslides along SdF continued to be recorded after the development of the lava flow on SdF.
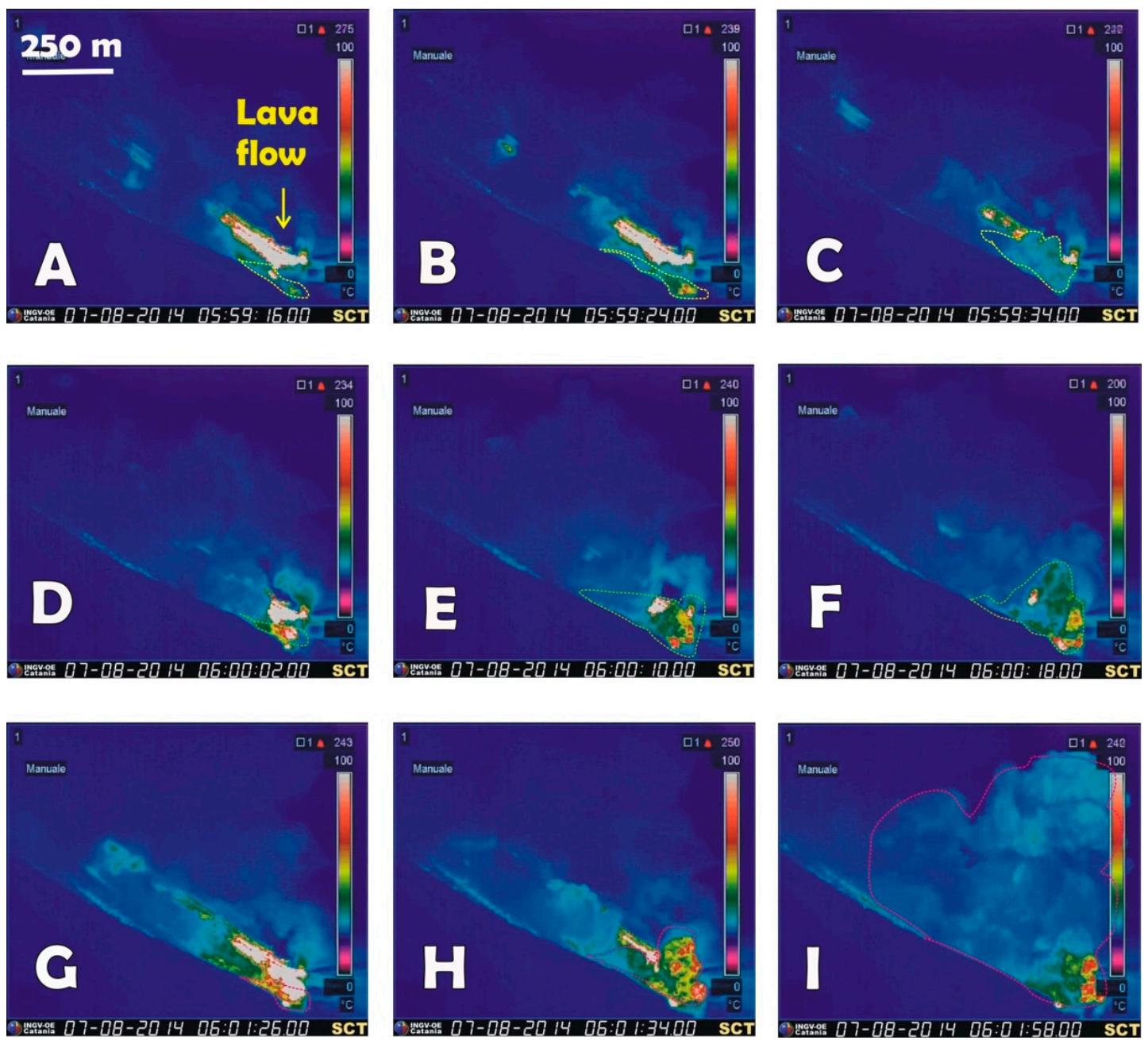

Figure 8. Lava flows (white) and hot avalanches (yellow, green, and purple dotted outline) spreading along the lower slope of Sciara del Fuoco and to the sea, as observed by the thermal images recorded by the SCT camera located at Labronzo, $100 \mathrm{~m}$ a.s.l. on the east side of the Sciara on 7 August 2014. See Figure $1 \mathrm{~b}$ for camera location. (A-C): lava flow spreading to the coast, flanked by a hot avalanche (yellow dotted outline) at 5:59; (D-F): another hot avalanche spreading at 6:00 (yellow dotted line); (G-I): a much bigger hot avalanche spreading at 6:01 (red dotted outline) forming a conspicuous dust cloud).

In the period between the acquisitions of the two DEMs (May 2012-May 2017), large topographic changes occurred. The areas interested in volume gain and loss are shown in Figure 9, which includes the crater terrace and the SdF depression. The largest variations were related to the emplacement of the 2014 lava flow field in the NE part of the SdF (Figure 9). The total emplaced volume is 
$3.07 \pm 0.37 \times 10^{6} \mathrm{~m}^{3}$, calculated inside the black dashed line. The average thickness of lava was $10.45 \pm 1.27 \mathrm{~m}$, with the maximum value reaching $35 \mathrm{~m}$ (Figure 9, profile 1).

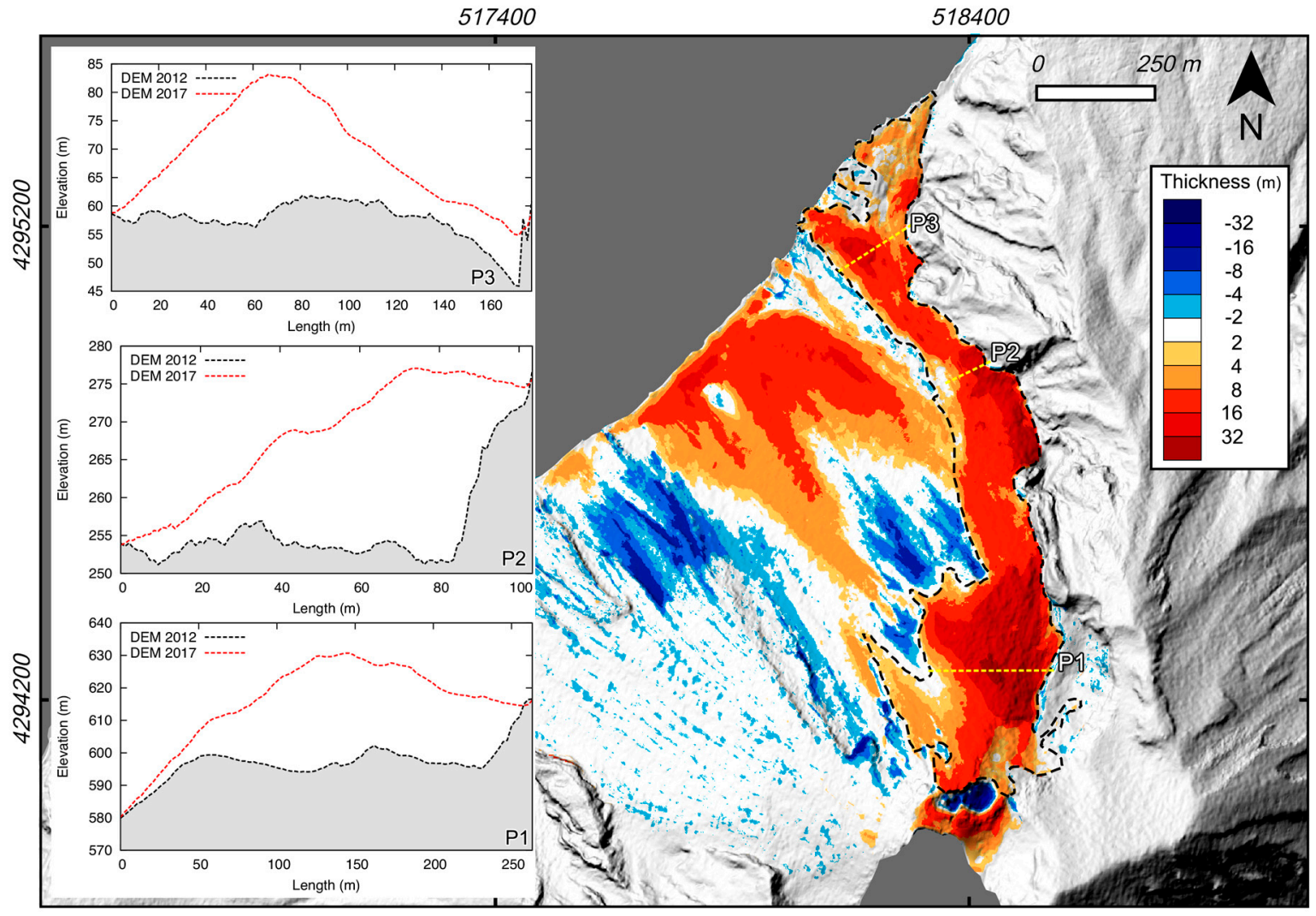

Figure 9. Stromboli topographic changes detected comparing 2012 and 2017 DEMs. Dashed black line encloses the area covered by the 2014 lava flow. Dashed yellow lines, labelled with P1, P2 and P3, show the position of the profiles along the flow represented in the insets.

In the central part of the SdF, between 0 and $\sim 518 \mathrm{~m}$ a.s.l., an increased volume of $1.70 \pm 0.30 \times 10^{6} \mathrm{~m}^{3}$ has been estimated, with an average thickness of $7.11 \pm 1.27 \mathrm{~m}$. This volume is related to the accumulation of volcaniclastic material derived from the erosion of the $\mathrm{SdF}$, from the overflow-induced landslides, and from the NEC-talus collapse [7].

\section{Discussion}

The run-up phase of the 2014 flank eruption was characterized by very vigorous explosive activity and episodic lava overflows from the crater terrace. This activity was preceded by an increase in the displacement rate towards the sensor of the crater terrace at anomalous level since the end of May 2014, and by frequent landslides along the SdF. Ground deformation of the crater terrace strongly increased on 26 July 2014 and was followed by increase of the volcanic tremor and explosion-quake amplitude, starting approximately on 2 August 2014. The explosive activity peaked on 5-6 August 2014, anticipating by $\sim 1$ day the increase in the displacement rate towards the sensor (inflation of the crater terrace).

Different authors $[1,3,6]$ suggested that the 2014 eruption was triggered by a gradual recharge of the shallow plumbing system and upper conduits. The $\mathrm{SO}_{2}$ flux in the persistent Stromboli plume has been measured for two months before the onset of the eruption, detecting a strong increase above normal activity in the $\mathrm{SO}_{2}$ pulses (puffing and explosions) before the effusion onset. This is consistent with the increase in gas bubble supply and magma transport rate feeding the uppermost storage system at Stromboli [47]. Ground displacement is consistent with the presence of a very shallow 
reservoir below the crater terrace [2]. Long-term (month to weeks) increase in the ground deformation recorded by the GBInSAR in the crater terrace area, as well as the long-term rise of the VLP seismic source towards the surface [5,6], are associated with the accumulation of magma in the uppermost storage system at Stromboli [2]. Contrarily, the detected increase in short-term (days to hours) ground deformation and amplitude of volcanic tremor are associated with the impulsive bulk degassing from the shallow plumbing system [35,48], whereas the increase in the explosion number and intensity and amplitude of explosion quakes are indicative of the increase in the release rate and overpressure intensity of individual explosions.

One of the most interesting aspects of the data presented here is the relationship between the instability events and the effusive activity at Stromboli volcano (Figure 10). Other authors have already shown the critical state of Stromboli during the very early stages of effusive eruptions $[2,5,11,22,49]$. During the run-up to the 2014 flank eruption, gravel flows consisting of mixed breccia and loose volcaniclastic deposits were generated mainly in two ways: (i) by the crumbling of the overflows, or (ii) by the collapse of some portions of the external part of the crater terrace and apex of the hornitos (Figure 2). The second type of collapse is a recurring phenomenon at Stromboli, occurring when there is a large accumulation of magma below the crater terrace (causing overflows, increase in the frequency of explosions, spattering activity, inflation of the whole summit). Furthermore, weakness of the crater wall (e.g., induced by the strong explosive activity on 5 August 2014), and mechanical erosion caused by vent opening and by lava fingering, may have triggered the NEC-hornito collapse on 6 August 2014 [48]. Here we have documented for the first time that, after the NEC-hornito collapse, eruptive vents migrated from south to north (Figure 10a). Overflows and mass-wasting in the NEC-hornito area preceded the formation of fracture below the NEC1 (Figure 10b) by $\sim 11 \mathrm{~h}$, and the onset of the flank eruption and NEC1 collapse by $\sim 15 \mathrm{~h}$, suggesting that 11-15 h before the onset of the effusive eruption, the crater terrace was full of magma. Then, the location of effusive vents displayed a clockwise rotation along the rim of the crater terrace, from the NEC-hornito towards NEC2 and NEC1 (Figure 2), and finally magma migrated towards the NEC-talus, inducing fracture opening and landslides occurrence. This process suggested a gradual pressurization and/or expansion of the feeder dike along a SW-NE direction, which is also the main tectonic trend of the island [49,50]. Lava started to outflow from a first vent (V1; Figure 10c) before the NEC-talus collapse and shifted at vent V2 simultaneously with the beginning of the NEC-talus landslide (Figure 10d). There could be different explanations for this vent shift:

1. a structural barrier generated by the presence of a buried structure $[51,52]$ or different stratified material (Figure 2b), which in turn has caused the magma-filled fracture to re-orientate [53,54];

2. magma to flow from V1 at V2 in response to the tensile stress occurring in the talus produced by the downwards displacement observed by GBInSAR.

It is important to emphasize that this shift has prevented the dike from intruding within the SdF, as happened in the early stages of past eruptions (e.g., the 2007 eruption) [8]. Instead during the first days of the 2002-03 flank eruption, the intrusion of magma propagating laterally from the conduit towards a lower altitude was considered the cause that destabilized the SdF slope, with the triggering of tsunamigenic landslides on 30 December 2002 [22-25].

The flank eruption onset produced the drainage of a superficial magma reservoir [5,49], inducing ground deflation [55], a deepening of the VLP seismic source [5], and the cessation of summit explosive activity [5].

The volume of the drained magma can have critical implications on the eruption style and on its transition from effusive to explosive [56]. A previous author [4] calculated a total bulk volume of $7.4 \times 10^{6} \mathrm{~m}^{3}$ using data derived by the new satellite Technology Experiment Carrier-1 (TET-1) by the German Aerospace Center (DLR), whereas others [5] evaluated a total bulk volume of $5.5 \times 10^{6} \mathrm{~m}^{3}$ by thermal images from satellites using the Moderate Resolution Imaging Spectroradiometer (MODIS) sensor on-board the Terra and Aqua satellites. This last value was also confirmed by [57]. In MODIS approach, the error is usually estimated at 50\% [58]. 

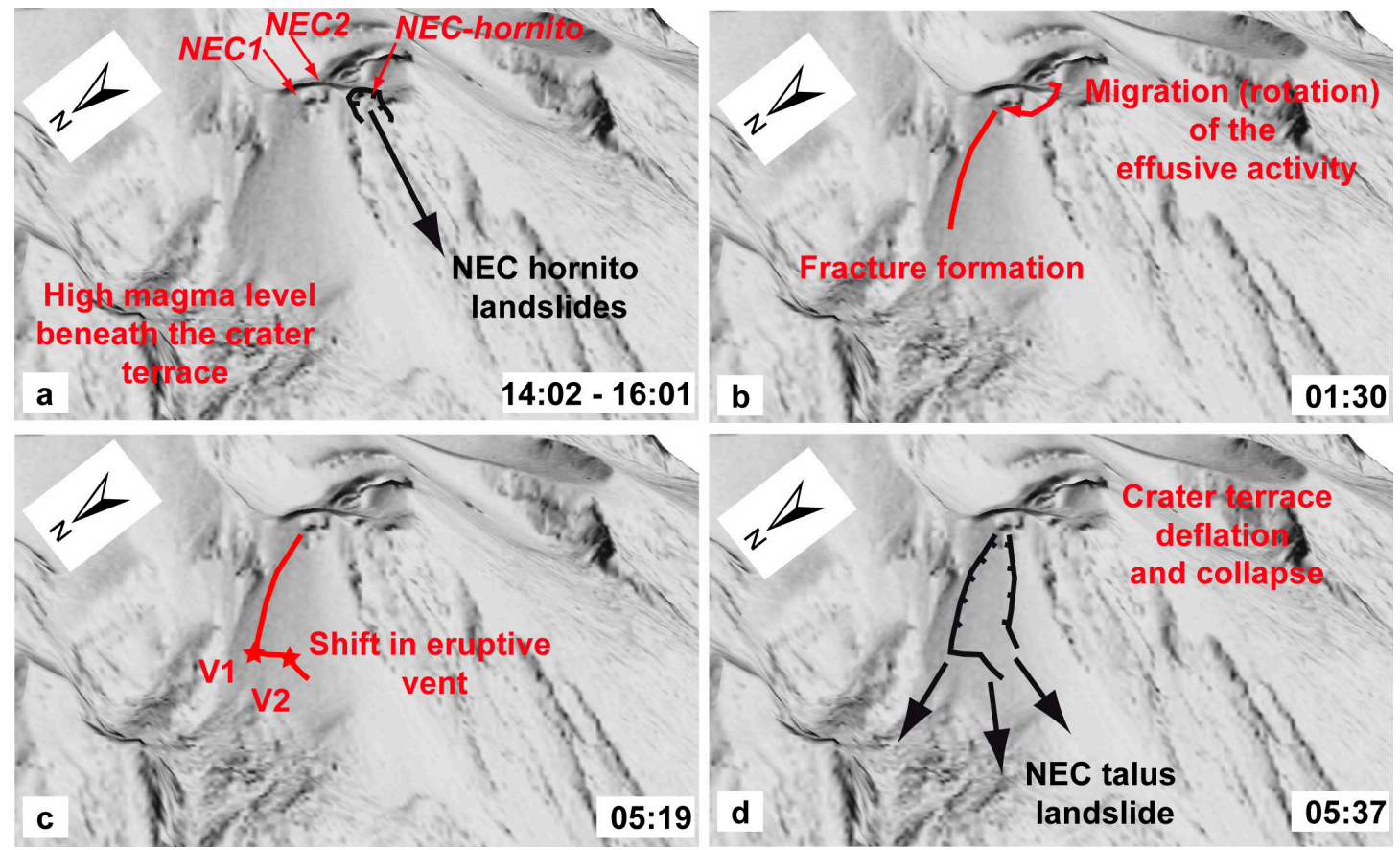

Figure 10. Schematic sketches representing the onset of the 2014 flank eruption as reconstructed on the basis of the new data presented in this paper. (a) The run-up phase of the 2014 flank eruption was characterized by high magma level beneath the crater terrace, which peaked on 6 August 2014 morning, with the occurrence of a large overflow from the NEC-hornito, triggering its collapse. Then the activity migrated from the NEC-hornito towards the NEC1. (b) The onset of the eruption coincided with the lateral dike propagation from the crater terrace along a NE-SW direction, triggering the instability of the NEC-talus, as evidenced by the increase in displacement rate at NEC-talus (until the loss of coherence in the GBInSAR data, compare with Figure 5) and landslides number (Figure 7). (c) Then the shift in the effusive vent from V1 to V2 occurred, (d) closely related to the NEC-talus collapse. Magmatic and mass-wasting phenomena are represented in red and in black, respectively.

To improve the volume estimation, we calculated the topographic change by comparing the 2012 and 2017 DEMs. This approach considers the volume variations due to erosion and accumulation occurred between the two acquisitions, therefore also the topographic changes occurred before or after the eruption and the volume of the lava flow emplaced below sea level during the first days of the eruption. However, in this area there was no evidence of significant erosive phenomena [7], and moreover the evidence of large accumulation (i.e., more than $1-2 \times 10^{6} \mathrm{~m}^{3}$ ) of lava or a debris flow under the sea is still missing [28].

We estimated that during the 2014 flank eruption, a volume of $3.07 \pm 0.37 \times 10^{6} \mathrm{~m}^{3}$ of lava was emplaced on the steep SdF slope, i.e., most of the volume emplaced in the subaerial part of the volcano. This value is close to the previous estimations of $5.5 \times 10^{6} \mathrm{~m}^{3}[5,57]$, which however comprises also the minor portion emplaced below sea level.

Some authors [57] proposed that the critical factor for triggering the most violent explosive events (paroxysms, [59-61]) is the decompression rate, suggesting that rates $>10 \mathrm{~Pa} \mathrm{~s}^{-1}$ can potentially favor the ascent of gas-rich magma batches responsible for the paroxysmal explosions that occurred at Stromboli during the 2002-03 and 2007 flank eruptions.

A critical aspect is that the paroxysmal explosions of both 5 April 2003 and 15 March 2007 occurred while effusive activity was still going on, and when the lava effusion rate (related to the magma decompression rate) was decreasing with respect to the initial phases of the eruptions. Moreover, the 2002-03 and 2014 flank eruptions were characterized by the same mean effusion 
rate [57] but, differently from the 2002-03, the 2014 eruption did not produce any paroxysm during the effusive activity.

A different approach to understand the transition from effusive to explosive style can be obtained by estimating the cumulated effusive volume. In fact, a previous author [56] proposed that the erupted volume during flank eruptions at Stromboli is very important for hazard estimation, because it is considered a key factor for the triggering of paroxysmal explosive activity. Calvari et al. [56] proposed that there is an erupted magma bulk volume limit of $6.5 \pm 1 \times 10^{6} \mathrm{~m}^{3}$. Once that this volume is poured out, for example by drainage due to the opening of a flank fissure, the decompression induced on the shallow storage can trigger paroxysmal activity, by bringing at shallow levels the gas-rich magma that is in the lower conduit [62-64]. Calvari et al. [56] point out that the rate of effusion, and consequently the decompression rate, is less crucial to trigger powerful explosive activity. This interesting aspect has also been observed trough laboratory experiments allowing direct observations of explosive expansion of a slowly decompressed magma analog [65]. The analog experiments highlighted that under these conditions an explosive eruption would only occur when sufficient magma was spilled from the conduit, in agreement with the considerations of [56]. The inferred volume of 2014 emitted lava $\left(3.07 \pm 0.37 \times 10^{6} \mathrm{~m}^{3}\right)$, even adding $1-2 \times 10^{6} \mathrm{~m}^{3}$ of underwater volume not measurable with our DEMs approach, is below the limit of $6.5 \pm 1 \times 10^{6} \mathrm{~m}^{3}$ suggested by [56] and, therefore, consistent with the absence of the paroxysmal explosion. This consideration also explains the different behavior of the 2014 eruption (with absence of paroxysmal activity), respect to the 2002-03 eruption (with paroxysmal explosion). In fact, although the two eruptions had the same mean effusion rate, the 2014 emitted volume did not reach the critical limit $\left(6.5 \times 10^{6} \mathrm{~m}^{3}\right)$ that was instead overcome by the 2002-03 eruption.

\section{Conclusions}

Integration of in situ and remote-sensing measurements can strongly support the management of eruptive crises at active volcanoes. In this paper, data from the in situ (visible and infrared) live-cam and seismic monitoring network, measuring the ground motion in the seismic band $(0.02-10 \mathrm{~Hz})$, have been integrated with ground displacement recorded by a GBInSAR device. Furthermore, to constrain the erupted lava volume, DEMs from LiDAR and PLEIADES-1 tri-stereo were compared, also supported by the high-resolution PLEIADES-1 optical images, supporting the areal mapping of the 2014 lava flow field. The main findings are:

- live-cam and explosion-quake data revealed that the explosive activity peaked between 5 and 6 August 2014, whereas the GBInSAR device recorded a drastic increase in the displacement rate since the morning of 6 August, consistent with a strong inflation of the crater terrace;

- ground displacement started to show evidence of sliding in the crater terrace after the 6 August 2014 evening, as also evidenced by seismic signals;

- the onset of the 2014 flank eruption involved the breaching of the summit cone with emplacement of a landslide along the SdF (anticipated by the GBInSAR measurements, observed by the live cam, and recorded by the seismic data), the opening of an eruptive fissure on the NE flank of the cone (observed by the live cam), and the effusion of lava from the crater rim at first and from the eruptive fissure later, feeding the 2014 lava flow field;

- the eruption was characterized by the lava effusion along the SdF from a fissure at $650 \mathrm{~m}$ above sea level (a.s.1.) that lasted until 13 November 2014, with a total volume of $3.07 \pm 0.37 \times 10^{6} \mathrm{~m}^{3}$ of lava emplaced on the steep SdF slope;

- this volume is below the limit of $6.5 \pm 1 \times 10^{6} \mathrm{~m}^{3}$ expected for triggering a paroxysmal explosion.

This work highlights the importance of considering data from in situ sensors and remote-sensing platforms in monitoring active volcanoes. Comparison of data from live-cams, seismic monitoring, and ground displacements recorded by GBInSAR devices provide information about the eruptive activity, nowcasting the shift in eruptive style from effusive to explosive. At the same time, the landslide activity during the run-up and onset phases could be forecasted and tracked using the integration of 
data from the GBInSAR and the seismic landslide index. Finally, the use of airborne and space-borne DEMs permitted the detection of topographic changes induced by the eruptive activity, allowed for the estimation of the total erupted volumes.

Supplementary Materials: The following are available online at http:/ /www.mdpi.com/2072-4292/10/12/2035/s1, Text 1. Supporting information to the main text.

Author Contributions: Conceptualization: F.D.T., S.C., A.B., L.D., T.N., A.F.; Live-cam data analysis: S.C., A.C.; Seismic data analysis: L.D., A.E.; GBInSAR data analysis: F.D.T., T.N., N.C.; DEMs comparison: A.F., M.F.; Writing-Original Draft Preparation: F.D.T., S.C., A.B., L.D., A.F.; Writing—Review \& Editing: T.N., A.E., M.F., N.C.

Funding: This work has been financially supported by the "Presidenza del Consiglio dei Ministri - Dipartimento della Protezione Civile" (Presidency of the Council of Ministers - Department of Civil Protection) within the framework of the InGrID2015-2016 and SAR.NET2017 projects (Scientific Responsibility: NC); this publication, however, does not reflect the position and the official policies of the Department. FDiT has been supported by a post-doc fellowship founded by the "Università degli Studi di Firenze - Ente Cassa di Risparmio di Firenze" (D.R. n. 127804 (1206) 2015; “Volcano Sentinel" project). This work has been financially supported by "Volcano Sentinel—extension" project (Call: "Settore ricerca scientifica e innovazione tecnologica"; founded by: Ente Cassa di Risparmio di Firenze. Scientific Responsibility: FeDiT).

Acknowledgments: For scientific, technical, logistic support during the 2014 Stromboli flank eruption, we thank: (UNIFI staff) Federica Bardi, Giuseppe De Rosa, Matteo Del Soldato, Giulia Dotta, Emanuele Intrieri, Teresa Salvatici, Lorenzo Solari, Luca Tanteri; (INGV-OE Staff) The technicians of INGV-OE are thanked for the maintenance of the camera monitoring network; (INGV-OV Staff) The technicians of INGV-OV are thanked for the maintenance of the seismic monitoring network; (DPC staff) Chiara Cardaci, Stefano Ciolli, Luigi Coppola, Domenico Mangione, Damiano Piselli, Antonio Ricciardi, Salvatore Zaia. F.D.T. would like to thank Carmine Allocca, Diego Coppola, Dario Delle Donne, Riccardo Genco, Giorgio Lacanna, Marco Laoiolo, Marco Pistolesi, Sébastien Valade for their constructive discussions during and after the 2014 flank eruption.

Conflicts of Interest: The authors declare no conflict of interest.

\section{References}

1. Rizzo, A.L.; Federico, C.; Inguaggiato, S.; Sollami, A.; Tantillo, M.; Vita, F.; Bellomo, S.; Longo, M.; Grassa, F.; Liuzzo, M. The 2014 effusive eruption at Stromboli volcano (Italy): Inferences from soil $\mathrm{CO}_{2}$ flux and 3He/4He ratio in thermal waters. Geophys. Res. Lett. 2015, 42, 2235-2243. [CrossRef]

2. Di Traglia, F.; Battaglia, M.; Nolesini, T.; Lagomarsino, D.; Casagli, N. Shifts in the eruptive styles at Stromboli in 2010-2014 revealed by ground-based InSAR data. Sci. Rep. 2015, 5, 13569. [CrossRef] [PubMed]

3. Inguaggiato, S.; Vita, F.; Cangemi, M.; Mazot, A.; Sollami, A.; Calderone, L.; Morici, S.; Paz, M.P.J. Stromboli volcanic activity variations inferred from observations of fluid geochemistry: 16 years of continuous monitoring of soil $\mathrm{CO}_{2}$ fluxes (2000-2015). Chem. Geol. 2017, 469, 69-84. [CrossRef]

4. Zakšek, K.; Hort, M.; Lorenz, E. Satellite and ground based thermal observation of the 2014 effusive eruption at Stromboli volcano. Remote Sens. 2015, 7, 17190-17211. [CrossRef]

5. Valade, S.; Lacanna, G.; Coppola, D.; Laiolo, M.; Pistolesi, M.; Delle Donne, D.; Genco, R.; Marchetti, E.; Ulivieri, G.; Allocca, C.; et al. Tracking dynamics of magma migration in open-conduit systems. Bull. Volcanol. 2016, 78, 78. [CrossRef]

6. Liotta, M.; Rizzo, A.L.; Barnes, J.D.; D’Auria, L.; Martelli, M.; Bobrowski, N.; Wittmer, J. Chlorine isotope composition of volcanic rocks and gases at Stromboli volcano (Aeolian Islands, Italy): Inferences on magmatic degassing prior to 2014 eruption. J. Volcanol. Geotherm. Res. 2017, 336, 168-178. [CrossRef]

7. Di Traglia, F.; Nolesini, T.; Ciampalini, A.; Solari, L.; Frodella, W.; Bellotti, F.; Fumagalli, A.; De Rosa, G.; Casagli, N. Tracking morphological changes and slope instability using spaceborne and ground-based SAR data. Geomorphology 2018, 300, 95-112. [CrossRef]

8. Calvari, S.; Lodato, L.; Steffke, A.; Cristaldi, A.; Harris, A.J.L.; Spampinato, L.; Boschi, E. The 2007 Stromboli flank eruption: Chronology of the events, and effusion rate measurements from thermal images and satellite data. J. Geophys. Res. Solid Earth 2010, 115, B04201. [CrossRef]

9. Calvari, S.; Bonaccorso, A.; Madonia, P.; Neri, M.; Liuzzo, M.; Salerno, G.G.; Behncke, B.; Caltabiano, T.; Cristaldi, A.; Giuffrida, G.; et al. Major eruptive style changes induced by structural modifications of a shallow conduit system: The 2007-2012 Stromboli case. Bull. Volcanol. 2014, 76, 841. [CrossRef]

10. Antonello, G.; Casagli, N.; Farina, P.; Leva, D.; Nico, G.; Sieber, A.J.; Tarchi, D. Ground-based SAR interferometry for monitoring mass movements. Landslides 2004, 1, 21-28. [CrossRef] 
11. Di Traglia, F.; Nolesini, T.; Intrieri, E.; Mugnai, F.; Leva, D.; Rosi, M.; Casagli, N. Review of ten years of volcano deformations recorded by the ground-based InSAR monitoring system at Stromboli volcano: A tool to mitigate volcano flank dynamics and intense volcanic activity. Earth Sci. Rev. 2014, 139, 317-335. [CrossRef]

12. Martini, M.; Giudicepietro, F.; D'Auria, L.; Esposito, A.M.; Caputo, T.; Curciotti, R.; Raffaele Curciotti De Cesare, W.; Orazi, M.; Scarpato, G.; Caputo, A.; et al. Seismological monitoring of the February 2007 effusive eruption of the Stromboli volcano. Ann. Geophys. 2007, 50, 775-788.

13. Martini, M.; D'Auria, L.; Caputo, T.; Giudicepietro, F.; Peluso, R.; Caputo, A.; De Cesare, W.; Esposito, A.M.; Orazi, M.; Scarpato, G. Seismological insights on the shallow magma system. In The Stromboli Volcano: An Integrated Study of the 2002-2003 Eruption; American Geophysical Union: Washington, DC, USA, 2008; pp. 279-286.

14. Marotta, E.; Calvari, S.; Cristaldi, A.; D'Auria, L.; Di Vito, M.A.; Moretti, R.; Peluso, R.; Spampinato, L.; Boschi, E. Reactivation of Stromboli's summit craters at the end of the 2007 effusive eruption detected by thermal surveys and seismicity. J. Geophys. Res. 2015, 120, 7376-7395. [CrossRef]

15. Di Traglia, F.; Bartolini, S.; Artesi, E.; Nolesini, T.; Ciampalini, A.; Lagomarsino, D.; Martí, J.; Casagli, N. Susceptibility of intrusion-related landslides at volcanic islands: The Stromboli case study. Landslides 2018, 15, 21-29. [CrossRef]

16. Kokelaar, P.; Romagnoli, C. Sector collapse, sedimentation and clast population evolution at an active island-arc volcano: Stromboli, Italy. Bull. Volcanol. 1995, 57, 240-262. [CrossRef]

17. Tibaldi, A. Multiple sector collapses at Stromboli volcano, Italy: How they work. Bull. Volcanol. 2001, 63, 112-125. [CrossRef]

18. Maramai, A.; Graziani, L.; Tinti, S. Tsunamis in the Aeolian Islands (southern Italy): A review. Mar. Geol. 2005, 215, 11-21. [CrossRef]

19. Barberi, F.; Rosi, M.; Sodi, A. Volcanic hazard assessment at Stromboli based on review of historical data. Acta Vulcanol. 1993, 3, 173-187.

20. Rosi, M.; Pistolesi, M.; Bertagnini, A.; Landi, P.; Pompilio, M.; Di Roberto, A. Stromboli volcano, Aeolian Islands (Italy): Present eruptive activity and hazards. Geol. Soc. Lond. Mem. 2013, 37, 473-490. [CrossRef]

21. De Fino, M.; La Volpe, L.; Falsaperla, S.; Frazzetta, G.; Neri, G.; Francalanci, L.; Rosi, M.; Sbrana, A. The Stromboli eruption of 6 December 1985-25 April 1986: Volcanological, petrological and seismological data. Rend. Della Soc. Italiana Mineral. Petrol. 1988, 43, 1021-1038.

22. Bonaccorso, A.; Calvari, S.; Garfi, G.; Lodato, L.; Patanè, D. Dynamics of the December 2002 flank failure and tsunami at Stromboli volcano inferred by volcanological and geophysical observations. Geophys. Res. Lett. 2003, 30. [CrossRef]

23. Casagli, N.; Tibaldi, A.; Merri, A.; Del Ventisette, C.; Apuani, T.; Guerri, L.; Fortuny-Guasch, J.; Tarchi, D. Deformation of Stromboli Volcano (Italy) during the 2007 eruption revealed by radar interferometry, numerical modelling and structural geological field data. J. Volcanol. Geotherm. Res. 2009, 182, 182-200. [CrossRef]

24. Carlà, T.; Intrieri, E.; Di Traglia, F.; Nolesini, T.; Gigli, G.; Casagli, N. Guidelines on the use of inverse velocity method as a tool for setting alarm thresholds and forecasting landslides and structure collapses. Landslides 2017, 14, 517-534. [CrossRef]

25. Tinti, S.; Pagnoni, G.; Zaniboni, F. The landslides and tsunamis of the 30th of December 2002 in Stromboli analysed through numerical simulations. Bull. Volcanol. 2006, 68, 462-479. [CrossRef]

26. Carlà, T.; Intrieri, E.; Di Traglia, F.; Casagli, N. A statistical-based approach for determining the intensity of unrest phases at Stromboli volcano (Southern Italy) using one-step-ahead forecasts of displacement time series. Nat. Hazards 2016, 84, 669-683. [CrossRef]

27. Acocella, V.; Neri, M.; Scarlato, P. Understanding shallow magma emplacement at volcanoes: orthogonal feeder dikes during the 2002-2003 Stromboli (Italy) eruption. Geophys. Res. Lett. 2006, 33. [CrossRef]

28. Lodato, L.; Spampinato, L.; Harris, A.J.L.; Calvari, S.; Dehn, J.; Patrick, M. The Morphology and Evolution of the Stromboli 2002-2003 Lava Flow Field: An Example of Basaltic Flow Field Emplaced on a Steep Slope. Bull. Volcanol. 2007, 69, 661-679. [CrossRef]

29. Di Traglia, F.; Nolesini, T.; Solari, L.; Ciampalini, A.; Frodella, W.; Steri, D.; Allotta, B.; Rindi, A.; Monni, N.; Marini, L.; et al. Lava delta deformation as a proxy for submarine slope instability. Earth Planet. Sci. Lett. 2018, 488, 46-58. [CrossRef] 
30. De Cesare, W.; Orazi, M.; Peluso, R.; Scarpato, G.; Caputo, A.; D'Auria, L.; Giudicepietro, F.; Martini, M.; Buonocunto, C.; Capello, M.; Esposito, A.M. The broadband seismic network of Stromboli volcano, Italy. Seismol. Res. Lett. 2009, 80, 435-439. [CrossRef]

31. Esposito, A.M.; D'Auria, L.; Giudicepietro, F.; Peluso, R.; Martini, M. Automatic recognition of landslides based on neural network analysis of seismic signals: An application to the monitoring of Stromboli volcano (Southern Italy). Pure Appl. Geophys. 2013, 170, 1821-1832. [CrossRef]

32. Muller, C.; del Potro, R.; Biggs, J.; Gottsmann, J.; Ebmeier, S.K.; Guillaume, S.; Cattin, P.-H.; Van der Laat, R. Integrated velocity field from ground and satellite geodetic techniques: Application to Arenal volcano. Geophys. J. Int. 2014, 200, 863-879. [CrossRef]

33. Schaefer, L.N.; Lu, Z.; Oommen, T. Dramatic volcanic instability revealed by InSAR. Geology 2015, 43, 743-746. [CrossRef]

34. Bonforte, A.; Guglielmino, F. Very shallow dyke intrusion and potential slope failure imaged by ground deformation: The 28 December 2014 eruption on Mount Etna. Geophys. Res. Lett. 2015, 42, 2727-2733. [CrossRef]

35. Frodella, W.; Ciampalini, A.; Bardi, F.; Salvatici, T.; Di Traglia, F.; Basile, G.; Casagli, N. A method for assessing and managing landslide residual hazard in urban areas. Landslides 2018, 15, 183-197. [CrossRef]

36. Di Traglia, F.; Cauchie, L.; Casagli, N.; Saccorotti, G. Decrypting geophysical signals at Stromboli Volcano (Italy): Integration of seismic and Ground-Based InSAR displacement data. Geophys. Res. Lett. 2014, 41, 2753-2761. [CrossRef] [PubMed]

37. Gleyzes, M.A.; Perret, L.; Kubik, P. Pleiades system architecture and main performances. Int. Arch. Photogramm. Remote Sens. Spat. Inf. Sci. 2012, 39, 537-542. [CrossRef]

38. Perko, R.; Raggam, H.; Gutjahr, K.; Schardt, M. Assessment of the mapping potential of Pléiades stereo and triplet data. ISPRS Ann. Photogramm. Remote Sens. Spat. Inf. Sci. 2014, 2, 103. [CrossRef]

39. Zhou, Y.; Parsons, B.; Elliott, J.R.; Barisin, I.; Walker, R.T. Assessing the ability of Pleiades stereo imagery to determine height changes in earthquakes: A case study for the El Mayor-Cucapah epicentral area. J. Geophys. Res. Solid Earth 2015, 120, 8793-8808. [CrossRef]

40. Bagnardi, M.; González, P.J.; Hooper, A. High-resolution digital elevation model from tri-stereo Pleiades-1 satellite imagery for lava flow volume estimates at Fogo Volcano. Geophys. Res. Lett. 2016, 43, 6267-6275. [CrossRef]

41. Rieg, L.; Klug, C.; Nicholson, L.; Sailer, R. Pléiades Tri-Stereo Data for Glacier Investigations-Examples from the European Alps and the Khumbu Himal. Remote Sens. 2018, 10, 1563. [CrossRef]

42. Favalli, M.; Fornaciai, A.; Mazzarini, F.; Harris, A.; Neri, M.; Behncke, B.; Pareschi, M.T.; Tarquini, S.; Boschi, E. Evolution of an active lava flow field using a multitemporal LIDAR acquisition. J. Geophys. Res. Solid Earth 2012, 115. [CrossRef]

43. James, F.; Roos, M. MINUIT Computer Code; Program D-506; CERN: Geneva, Switzerland, 1977.

44. Kolzenburg, S.; Favalli, M.; Fornaciai, A.; Isola, I.; Harris, A.J.L.; Nannipieri, L.; Giordano, D. Rapid updating and improvement of airborne LIDAR DEMs through ground-based SfM 3-D modeling of volcanic features. IEEE Trans. Geosci. Remote Sens. 2016, 54, 6687-6699. [CrossRef]

45. Richter, N.; Favalli, M.; de Zeeuw-van Dalfsen, E.; Fornaciai, A.; Fernandes, R.M.D.S.; Pérez, N.M.; Levy, J.; Silva Victória, S.; Walter, T.R. Lava flow hazard at Fogo Volcano, Cabo Verde, before and after the 2014-2015 eruption. Nat. Hazards Earth Syst. Sci. 2016, 16, 1925-1951. [CrossRef]

46. Favalli, M.; Fornaciai, A.; Nannipieri, L.; Harris, A.; Calvari, S.; Lormand, C. UAV-based remote sensing surveys of lava flow fields: A case study from Etna's 1974 channel-fed lava flows. Bull. Volcanol. 2018, 80, 29. [CrossRef]

47. Delle Donne, D.; Tamburello, G.; Aiuppa, A.; Bitetto, M.; Lacanna, G.; D'Aleo, R.; Ripepe, M. Exploring the explosive-effusive transition using permanent ultraviolet cameras. J. Geophys. Res. Solid Earth 2017, 122, 4377-4394. [CrossRef]

48. Calvari, S.; Intrieri, E.; Di Traglia, F.; Bonaccorso, A.; Casagli, N.; Cristaldi, A. Monitoring crater-wall collapse at active volcanoes: A study of the 12 January 2013 event at Stromboli. Bull. Volcanol. 2016, 78, 39. [CrossRef]

49. Neri, M.; Lanzafame, G. Structural features of the 2007 Stromboli eruption. J. Volcanol. Geotherm. Res. 2009, 182, 137-144. [CrossRef]

50. Bonaccorso, A.; Bonforte, A.; Gambino, S.; Mattia, M.; Guglielmino, F.; Puglisi, G.; Boschi, E. Insight on recent Stromboli eruption inferred from terrestrial and satellite ground deformation measurements. J. Volcanol. Geotherm. Res. 2009, 182, 171-181. [CrossRef] 
51. Finizola, A.; Sortino, F.; Lénat, J.F.; Valenza, M. Fluid circulation at Stromboli volcano (Aeolian Islands, Italy) from self-potential and $\mathrm{CO}_{2}$ surveys. J. Volcanol. Geotherm. Res. 2002, 116, 1-18. [CrossRef]

52. Giordano, G.; Porreca, M. Field observations on the initial lava flow and the fracture system developed during the early days of the Stromboli 2007 eruption. J. Volcanol. Geotherm. Res. 2009, 182, 145-154. [CrossRef]

53. Gudmundsson, A. Deflection of dykes into sills at discontinuities and magma-chamber formation. Tectonophysics 2011, 500, 50-64. [CrossRef]

54. Gudmundsson, A. Strengths and strain energies of volcanic edifices: Implications for eruptions, collapse calderas, and landslides. Nat. Hazards Earth Syst. Sci. 2012, 12, 2241-2258. [CrossRef]

55. Bonaccorso, A.; Gambino, S.; Guglielmino, F.; Mattia, M.; Puglisi, G.; Boschi, E. Stromboli 2007 eruption: Deflation modeling to infer shallow-intermediate plumbing system. Geophys. Res. Lett. 2008, 35. [CrossRef]

56. Calvari, S.; Spampinato, L.; Bonaccorso, A.; Oppenheimer, C.; Rivalta, E.; Boschi, E. Lava effusion-A slow fuse for paroxysms at Stromboli volcano? Earth Planet. Sci. Lett. 2011, 301, 317-323. [CrossRef]

57. Ripepe, M.; Pistolesi, M.; Coppola, D.; Delle Donne, D.; Genco, R.; Lacanna, G.; Laiolo, M.; Marchetti, E.; Ulivieri, G.; Valade, S. Forecasting Effusive Dynamics and Decompression Rates by Magmastatic Model at Open-vent Volcanoes. Sci. Rep. 2017, 7, 3885. [CrossRef]

58. Coppola, D.; Laiolo, M.; Piscopo, D.; Cigolini, C. Rheological control on the radiant density of active lava flows and domes. J. Volcanol. Geotherm. Res. 2013, 249, 39-48. [CrossRef]

59. Calvari, S.; Spampinato, L.; Lodato, L.; Harris, A.J.; Patrick, M.R.; Dehn, J.; Burton, M.; Andronico, D. Chronology and complex volcanic processes during the 2002-2003 flank eruption at Stromboli volcano (Italy) reconstructed from direct observations and surveys with a handheld thermal camera. J. Geophys. Res. Solid Earth 2015, 110. [CrossRef]

60. Calvari, S.; Spampinato, L.; Lodato, L. The 5 April 2003 vulcanian paroxysmal explosion at Stromboli volcano (Italy) from field observations and thermal data. J. Volcanol. Geotherm. Res. 2006, 149, 160-175. [CrossRef]

61. Rosi, M.; Bertagnini, A.; Harris, A.J.L.; Pioli, L.; Pistolesi, M.; Ripepe, M. A case history of paroxysmal explosion at Stromboli: Timing and dynamics of the 5 April 2003 event. Earth Planet. Sci. Lett. 2006, 243, 594-606. [CrossRef]

62. Bertagnini, A.; Métrich, N.; Landi, P.; Rosi, M. Stromboli volcano (Aeolian Archipelago, Italy): An open window on the deep-feeding system of a steady state basaltic volcano. J. Geophys. Res. 2003, 108, 2336. [CrossRef]

63. Métrich, N.; Bertagnini, A.; Landi, P.; Rosi, M.; Belhadj, O. Triggering mechanism at the origin of paroxysms at Stromboli (Aeolian Archipelago, Italy): The 5 April, 2003 eruption. Geophys. Res. Lett. 2005, 32, L10305. [CrossRef]

64. Bonaccorso, A.; Calvari, S.; Linde, A.; Sacks, S.; Boschi, E. Dynamics of the shallow plumbing system investigated from borehole strainmeters and cameras during the 15 March 2007 Vulcanian paroxysm at Stromboli volcano. Earth Planet. Sci. Lett. 2012, 357-358, 249-256. [CrossRef]

65. Rivalta, E.; Pascal, K.; Phillips, J.; Bonaccorso, A. Explosive expansion of a slowly decompressed magma analogue: Evidence for delayed bubble nucleation. Geochem. Geophys. Geosyst. 2013, 14, 3067-3084. [CrossRef] 